Удк 331.5.024.5

DOI https://doi.org/10.32851/2708-0366/2020.4.12

Кирилов Ю.Є.

доктор економічних наук, професор, профессор кафедри публічного управління та адміністрування,

Херсонський державний аграрно-економічний університет

ORCID: https://orcid.org/0000-0001-5061-2644

Крикунова В.М.

кандидат економічних наук, доцент, доцент кафедри готельно-ресторанного та туристичного бізнесу й іноземних мов,

Херсонський державний аграрно-економічний університет

ORCID: https://orcid.org/0000-0001-5710-8029

Жосан Г.В.

кандидат економічних наук, доцент,

доцент кафедри менеджменту та інформаційних технологій,

Херсонський державний аграрно-економічний університет

ORCID: https://orcid.org/0000-0002-3577-6701

Kyrylov Yurii, Krykunova Viktoriia, Zhosan Hanna

Kherson State Agrarian and Economic University

\title{
БРЕНДИНГ ТЕРИТОРІЇ ЯК ІНСТРУМЕНТ СТИМУЛЮВАННЯ МОЛОДІЖНОГО ПІДПРИєМНИЦТВА
}

\section{BRANDING TERRITORY AS A TOOL TO STIMULATE YOUTH ENTREPRENEURSHIP}

У статті обтрунтовано напрями, за якими брендинг території сприяс розвитку молодіжного підприємництва $і$ забезпечує реалізацію його сочзільно-економічних функцій. Уточнено та розширено поняття «брендинг території» з урахуванням аспекту взаємного впливу та взаємодії изого інструментарію з феноменом і проиесами молодіжного підприємниитва на основі відповідності економічних та соиіальних інтересів зачікавлених сторін. Виділено основні напрями формування позитивного іміджу та репутації регіону, за кожним з яких проаналізовано досвід застосування інноваційних інструментів стосовно стимулювання молодіжного підприємництва. У ході дослідження встановлено, що стратегія брендингу дає змогу здійснювати завдання формування детермінантів підвищзення рівня самоототожнення/самоідентифікації молоді з територією проживання та, як наслідок, конструювання стійкої позитивної регіональної ідентичності й мотивації до реалізації підприємницької активності та ін.

Ключові слова: брендинг території, молодіжне підприємництво.

В статье обоснованы направления, по которым брендинг территории способствует развитию молодежного предпринимательства и обеспечивает реализацию его социиально-экономических функций. Уточнено и расширено понятие «брендинг территории» с учетом аспекта взаимного влияния и взаимодействия этого инструментария с феноменом и процессами молодежного предпринимательства на основе соответствия экономических и социальных интересов заинтересованных сторон. Выделены основные направления формирования положительного имиджа и репутации региона, проанализирован опыт применения инновационных инструментов по стимулированию молодежного предпринимательства. В ходе исследования установлено, что стратегия брендинга позволяет осуществлять задачи формирования детерминант повышения уровня самоотождествления/самоидентификации молодежи с территорией проживания и, как следствие, конструирования устойчивой положительной региональной идентичности и мотивации к реализации предпринимательской активности и т. д.

Ключевые слова: брендинг территории, молодежное предпринимательство. 
The article substantiates the areas in which the territory branding promotes the development of youth entrepreneurship and its socio-economic functions implementation. The concept of "territory branding" has been clarified and expanded, taking into account the aspect of mutual influence and interaction of these tools with the phenomenon and processes of youth entrepreneurship according to the compliance of economic and social interests of stakeholders. The main directions of the region positive image and reputation forming are identified. Each of them is analyzed referring to the experience of the youth entrepreneurship stimulation innovative tools. It was figured out that the branding strategy allows to carry out the following tasks: forming young people self-identification with the territory of residence and as a result-constructing a stable positive regional identity and motivation to do regional-oriented business; orientation of residents to local problems solving and increase their participation in the social and political life of the community; attracting new investors to the region; promotion of the local products (produced on the territory of the agent); the tourist flows' increase; drawing the attention of the authorities and supranational structures to the opportunities and threats of the region in terms of strategic partnership in programs and projects calls; promotion of the region attractiveness to potential migrants, especially to highly qualified professionals of working age and youth. The importance of territorial branding for young entrepreneurs is difficult to overestimate, because even with the most favorable economic conditions and the availability of highly qualified management staff, young people as a business entity are more vulnerable than other age groups for a number of reasons. The implementation of the above tasks will result in: the development of an effective information infrastructure; ensuring a competitive market environment and strengthening the competitiveness of young entrepreneurs at the interregional and international levels; raising the level of technical and innovation-technological support of enterprises; creating attractive conditions for investing and intensifying the activities of credit institutions, in generalimproving access to financial resources; creation of conditions for restructuring of economically weak business entities; improving the organizational structure, forms and content of marketing at the level of the region and companies; development and implementation of social programs in the region to improve the quality of life.

Key words: territory branding, youth entrepreneurship.

Постановка проблеми. Територіальний брендинг можна охарактеризувати як актуальну парадигму територіального управління соціально-економічним розвитком, що відповідає пріоритетам сучасної геополітики та геоекономіки. Імідж і бренд, репутація і маркетинг території (країни, регіону) сьогодні стають ключовими ресурсами економіки, значущість яких особливо зростає в умовах невизначеності та нестабільності зовнішнього середовища. Актуальність брендингу територій зумовлена також процесами діджиталізації та інформатизації сучасної економічної системи, що визначає нові підходи до забезпечення конкурентних переваг економічних агентів та політичних суб'єктів. Імідж і бренд території, їі репутація у вітчизняних та зарубіжних суспільно-політичних і ділових колах стають основними чинниками просування загальнодержавних і регіональних економічних та політичних проєктів, привабливості умов реалізації підприємницької активності. Сучасний інструментарій територіального розвитку формує бізнес-клімат, визначає темпи та якість соціально-економічного розвитку, включаючи вектор бізнес-інтересів молодих підприємців, діяльність яких сприяє залученню інвестицій, розбудові соціальної сфери, забезпеченню ефективної зайнятості населення, розвитку історико-культурного потенціалу тощо.

Зазначене зумовлює актуальність вибраної теми дослідження, його мету та завдання.

Аналіз останніх досліджень і публікацій. Тематиці брендингу присвячено публікації значної кількості зарубіжних учених і практиків: Ф. Котлера, К. Асплунда, Д. Хайдера, І. Рейна, Д. Візгалова, П. Берга, С. Девіса, М. Кавараціса, Н. Котова, С. Зенкера, А. Лукареллі, Н. Мартіна, А. Моргана, Х. Різенбека, Б. Якобсена, І. Березіна. Найгрунтовнішими, на нашу думку, є праці С. Анхолта, що є основним творцем терміна placebrending і з 1998 р. постійно публікує наукові праці, присвячені різним аспектам брендингу територій. Поруч із працями Ф. Котлера, у яких уперше було обгрунтовано 
визначення території та ії̈ ресурсів як товару, ці наукові засади стали поштовхом до розвитку великої кількості суміжних понять, відомих у вітчизняній науці як регіональний брендинг, брендинг місць, брендинг територій тощо.

Але в працях вітчизняних науковців системно брендинг почали розглядати нещодавно. Дослідження зарубіжних і вітчизняних науковців переважно стосуються вивчення ролі товарних знаків і послуг, недостатньо уваги приділено територіальному брендингу та брендингу малих міст зокрема.

Молодіжне підприємництво є актуальним об'єктом аналізу вітчизняних та зарубіжних учених Л. Бокова, О. Дьяченко, С. Карева, А. Кобзєва, Л. Копєйкіної, С. Кортова, А. Куликова, Г. Лаптєва, С. Лендера, О. Молчанової, А. Мокроносова, І. Мошкина, Н. Судакової, Г. Широкова, Д. Шульгіна та ін. При цьому феномен молодіжного підприємництва активно вивчають наукові спільноти, і майже всі сходяться на думці, що розглядати його варто з урахуванням вікових особливостей підприємців.

А.В. Іванова, вивчаючи молодіжне підприємництво в контексті динамічного процесу, спрямованого на формування нових цінностей у бізнесі, вказує, що віковим критерієм віднесення молодих людей до даного сектору господарювання є 35 років [1]. Н.В. Ахіярова, погоджуючись з попереднім дослідником, відзначає специфічні якості молодих людей, знижуючи віковий ценз до 30 років, підкреслюючи, що саме у цієї групи спостерігається більш виражена схильність до інноваційності, вільної самореалізації та соціальної адаптації [2]. Тому, на думку багатьох дослідників, розвиток молодіжного підприємництва та залучення молоді до підприємницької діяльності характеризується високим потенціалом економічних та соціальних вигід.

Разом із тим автори наголошують на тісному взаємозв'язку наведених термінів із погляду потенціалу та важливості брендування території з метою формування умов для реалізації підприємницької активності молоді. Проте взаємний вплив брендингу територій та процесів у сфері молодіжного підприємництва є недостатньо недослідженим.

Формулювання цілей статті. Мета статті полягає в обгрунтуванні напрямів, за якими брендинг території сприяє розвитку молодіжного підприємництва для забезпечення реалізації його соціально-економічних функцій.

Виклад основного матеріалу. Для будь-якого регіону його імідж та репутація $\epsilon$ основою відносин із цільовими групами стейкхолдерів. Брендинг території спрямований на створення позитивних образів, асоціацій та репутації в думках як жителів, так і гостей регіонів і, як наслідок, формування лояльності до нього.

Брендинг як масове явище та об'єкт бухгалтерського обліку вперше з'явився у XIX ст. із виходом на ринок перших фірмових товарів, що швидко продаються. 3 того часу практика і теорія брендингу суттєво розвинулися в аспекті об'єкту, а також сфери застосування (табл. 1).

Термін «брендинг території» (place branding) увів до наукового обігу Саймон Анхольт у 1998 р. Учений також першим запропонував методику рейтингування національних брендів (Anholt Nation Brands Index), міст (Anholt City Brands Index) і брендів різних штатів США (Anholt State Brands Index).

С. Зенкер і Е. Браун у праці «Сутність бренду території - концептуальний підхід до брендингу території і територіальному бренд-менеджменту» адаптують поняття корпоративного бренду стосовно бренду регіону. 3 їхньої точки зору, бренд території - це комплекс асоціацій у свідомості споживачів, які базуються на візуальних, вербальних і поведінкових проявах особливостей території, що виражаються у цілях, комунікаціях, цінностях і спільній культурі регіональних стейкхолдерів, а також у загальному дизайні даної території [1, с. 3]. Велике значення при цьому має імідж бренду території, під яким розуміють те враження, яке складається у свідомості представників цільових аудиторій про регіон як про єдине ціле. 
Таблиця 1

Еволюція поняття «брендинг»

\begin{tabular}{|c|c|c|}
\hline № & $\begin{array}{l}\text { Автор/джерело } \\
\text { (рік) }\end{array}$ & Визначення поняття «брендинг» \\
\hline 1 & I. Рожков (1999) & $\begin{array}{l}\text { Це діяльність зі створення довгострокових переваг для товару, за- } \\
\text { снована на спільних діях щодо посилення споживчої торгової мар- } \\
\text { ки, упаковки, рекламних повідомлень, управління матеріалами та } \\
\text { стимулювання збуту та інших рекламних елементів, об’єднаних } \\
\text { ідеєю певної характеристики та єдиного дизайну, виділяючи товар } \\
\text { із конкуренції та створюючи його імідж. }\end{array}$ \\
\hline 2 & \begin{tabular}{|l|} 
Словник \\
маркетингу (2000)
\end{tabular} & $\begin{array}{l}\text { Сукупність заходів, які компанія повинна здійснити для оптимізації } \\
\text { маркетингової суміші бренду. }\end{array}$ \\
\hline 3 & $\begin{array}{l}\text { Н. Добробабєнко } \\
(2000)\end{array}$ & $\begin{array}{l}\text { Це інвентаризація символічної політики та управління іміджем } \\
\text { шляхом усебічного використання стратегій та технологій марке- } \\
\text { тингу та управління. }\end{array}$ \\
\hline 4 & Е. Ромат (2001) & $\begin{array}{l}\text { Це маркетингова діяльність із метою створення особливого спо- } \\
\text { живчого досвіду, що включає імідж компанії та власника бренду, } \\
\text { створює цільовий сегмент ринкового ставлення до бренду. Брен- } \\
\text { динг можна розглядати як одну із синтетичних систем інструментів } \\
\text { маркетингових комунікацій, що включають деякі елементи системи } \\
\text { основних засобів маркетингових комунікацій: рекламу, зв’язки } 3 \\
\text { громадськістю, прямий маркетинг та стимулювання збуту. }\end{array}$ \\
\hline 5 & Ф. Шарков (2003) & $\begin{array}{l}\text { Це створення програми та управління брендом на ринку. Включає } \\
\text { створення, вдосконалення, репозиціонування, оновлення та зміну } \\
\text { стадії розвитку бренду, його розширення та поглиблення. }\end{array}$ \\
\hline 6 & $\begin{array}{l}\text { R. Olle \& D. Rui } \\
(2004)\end{array}$ & $\begin{array}{l}\text { Технологія, яка забезпечує стабільні характеристики товару, що ро- } \\
\text { бить його улюбленою покупкою, таким чином, підвищуючи конку- } \\
\text { рентоспроможність товару. }\end{array}$ \\
\hline 7 & А. Корол (2005) & $\begin{array}{l}\text { Інформаційна квінтесенція всієї фірми з бізнес-стратегії, результа- } \\
\text { том якої є всі ї̈ зусилля в маркетингу та менеджменті, а також у } \\
\text { сфері маркетингових комунікацій. }\end{array}$ \\
\hline 8 & $\begin{array}{l}\text { К. Архангельська } \\
(2006)\end{array}$ & $\begin{array}{l}\text { Діяльність, яка передбачає цілеспрямоване формування бренду - } \\
\text { унікальний імідж бренду у свідомості людей, які можуть не лише } \\
\text { диференціювати його від конкурентів, а й створити справжню ло- } \\
\text { яльність клієнтів до бренду. Окрім того, цей образ не є продуктом } \\
\text { випадкових уявлень про функціональні характеристики споживчих } \\
\text { товарів, і результат означає наші потужні зусилля щодо розроблен- } \\
\text { ня та застосування складних репрезентацій бренду, тобто його кон- } \\
\text { цепцій. }\end{array}$ \\
\hline 9 & $\begin{array}{l}\text { Міжнародне } \\
\text { консалтингове } \\
\text { агентство } \\
\text { «Brandflight» } \\
\text { (2009) } \\
\end{array}$ & $\begin{array}{l}\text { Система управління якістю та ефективність торгової марки, що за- } \\
\text { безпечує споживачам можливість передавати інформацію про стра- } \\
\text { тегічні ідеї компанії. Це, своєю чергою, збільшує цінність багатьох } \\
\text { підприємств не лише для акціонерів, а й для його партнерів. }\end{array}$ \\
\hline 10 & $\begin{array}{l}\text { Л. Шульгіна } \\
\text { та М. Лео (2011) }\end{array}$ & $\begin{array}{l}\text { Ця система обгрунтована, збалансований процес, який включає } \\
\text { планування та реалізацію маркетингових заходів для створення } \\
\text { торгової марки, план розвитку трансформації торгової марки на } \\
\text { торговій марці, особливо шляхом розроблення відповідної назви, } \\
\text { корпоративного стилю та дизайну, рекламних кампаній, проведення } \\
\text { стимулювання продажу акцій, цільовий PR, для формування бажа- } \\
\text { ного асоціативного досвіду у споживачів. }\end{array}$ \\
\hline
\end{tabular}


Однією із цільових аудиторій, важливим стейкхолдером територіальної громади $\epsilon$ функціонуючі або потенційні молоді підприємці - найдинамічніші суб'єкти підприємництва. Класичною дефініцією підприємництва $є$ його визначення як ризикової економічної діяльності, спрямованої на систематичне отримання прибутку від виробництва і продажу товарів, надання послуг, виконання робіт. Разом із тим молоді люди креативно мислять, амбітні, готові змінювати світ і ризикувати не лише з метою отримання прибутку. Дана соціальна група - найактивніша частина суспільства, яка швидко реагує на зміни в соціально-економічному житті, ефективно трансформує їх у позитивні наслідки не лише у бізнесовому аспекті, а й для розвитку місцевої громади та бренду території у цілому.

Авторами дано визначення категорії «молодіжне підприємництво» як особливого самостійного сегменту підприємництва, представленого підприємцями у віці до 35 років, які здійснюють ініціативно-інноваційну економічну діяльність ц різних організаційно-правових формах, ефективно акумулюють і використовують фактори виробництва відповідно до своїх специфічних особистісних якостей (гнучкість, мобільність, енергійність, інноваційна активність, схильність до ризику) для задоволення існуючих або нових суспільних потреб із метою отримання підприємницького доходу [13]. Мотивація до заняття бізнес-діяльністю при цьому значною мірою формується під впливом локальної економічної, політичної, соціальної ситуації, тобто наявного іміджу та репутації території.

Як зазначалося, завдання брендингу території - формування бажаного іміджу та репутації території у свідомості цільових аудиторій, при цьому можлива ситуація, коли для кожної з аудиторій буде розроблено власний таргетований інформаційний контент.

Завдання брендингу території відображено на рис. 1.

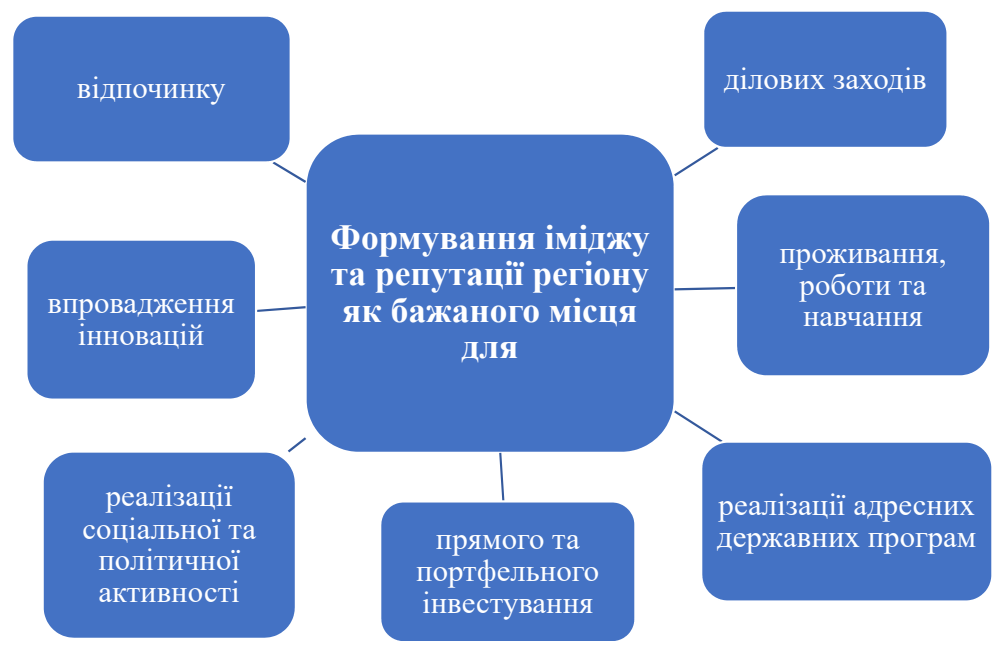

Рис. 1. Завдання брендингу території

Виходячи із цього, бренд регіону являє собою бренд-«парасолю», який об’єднує/ підпорядковує суббренди. I, як у випадку будь-яких брендів-«парасоль», під час прийняття рішення щодо кожного суббренда потрібно враховувати, який вплив матиме це рішення на материнський бренд та інші суббренди.

Яскравим прикладом такого комплексного підходу до бренду може служити компанія be Berlin, яка спочатку була орієнтована на жителів Берліна, потім як цільова 
аудиторія стали розглядатися туристи, пізніше - інвестори. Безумовно, для кожної 3 перерахованих груп як ключові були висунуті різні конкурентні переваги міста. Компанії з вигодою для себе можуть взяти участь у процесі формування і просування іміджу і репутації країни або регіону.

Можливий й «протилежно спрямований» брендинговий вплив: від бізнесу - на територію. На півдні Швеції розташовано низку конкуруючих виробників художнього скла. Деякі є визнаними світовими брендами, наприклад Orrefors i Kosta Boda. Щоб ще більше підсилити їхню перевагу, у 1980 р. було розроблено концептуально нову філософію бізнесу - Скляне королівство, у реалізації якої беруть участь скляні заводи з виробництва художнього скла для збільшення чисельності відвідувачів. Тепер щорічно Скляне королівство відвідують понад 1 млн туристів і покупців, що, природно, позитивно впливає на підприємства і територію у цілому [4].

Брендинг територій, сприяючи їх розвитку, є водночас впливовим інноваційним тригером молодіжного підприємництва через формування потужної мотивації до цього виду економічної діяльності, створення умов для його реалізації. Авторами виділено чотири групи стейкхолдерів молодіжного підприємництва: держава, соціальне середовище, освітнє середовище та бізнес-середовище. Кожна 3 виділених груп включає у себе декілька учасників [2]. Соціальне середовище включає населення, громадські організації, студентство; група «держава» - органи державної влади та органи місцевого самоврядування; освітнє середовище - це заклади освіти та інституції неформальної освіти, та бізнес-середовище включає у себе бізнес-асоціації та бізнес-структури. Кожна із цих груп стейкхолдерів впливає на формування бренду території та, відповідно, детермінанти реалізації бізнес-активності молоді. На основі результатів попередніх досліджень автори пропонують виділити інструменти та напрями стимулюючого впливу брендингу території на суббренд - молодіжне підприємництво.

1. Завдання брендингу: регіон - інвестиційно привабливий об'єкт (відбувається формування фінансової бази молодіжного підприємництва). Основними інструментами є усунення адміністративних бар'єрів (у тому числі із застосуванням інформаційних технологій) та зниження податкового навантаження. Чистий притік прямих іноземних інвестицій в економіку країни є чутливим індикатором інвестиційної діяльності (рис. 2). Його динаміка щодо української економіки є різноспрямованою у 2017-2020 pр. Протягом майже трьох років аналізованого періоду спостерігаються додатні показники чистого притоку ПІІ. У першому кварталі 2020 р. запаси ПІІ в національній економіці скоротилися на суму 1451 млн дол. США.

2. Безпосередньо пов'язаною 3 вищенаведеним завданням $\epsilon$ промоція території як місця для бізнесу: регіони слугують не лише об'єктом для інвестицій, a й є майданчиком для відкриття і комфортного ведення бізнесу. Одним із синтетичних індикаторів привабливості території з погляду інвестиційної та бізнес-діяльності є міжнародний рейтинг Doing Business Світового банку, в якому висвітлюється 12 складників підприємницької діяльності у 190 країнах світу, зокрема аналізують легкість відкриття бізнесу, роботу з дозволами на будівництво, отримання електроенергії, процедуру реєстрації власності, отримання кредиту, захист інтересів інвесторів, адміністрування податків, умови міжнародної торгівлі, забезпечення виконання контрактів, урегулювання неплатоспроможності, працевлаштування та укладання контрактів 3 урядом. Оцінка формується на підставі оцінювання 10 показників.

За даними дослідження, 10 найкращих місць у світі для ведення бізнесу у 2020 р. - Нова Зеландія (з оцінкою 86,8 зі 100), Сінгапур (86,2), Гонконгський ПАР, Китай $(85,3)$, Данія $(85,3)$, Республіка Корея (84), США (84), Грузія $(83,7)$, Великобританія $(83,5)$, Норвегія $(82,6)$ та Швеція $(82)$. 


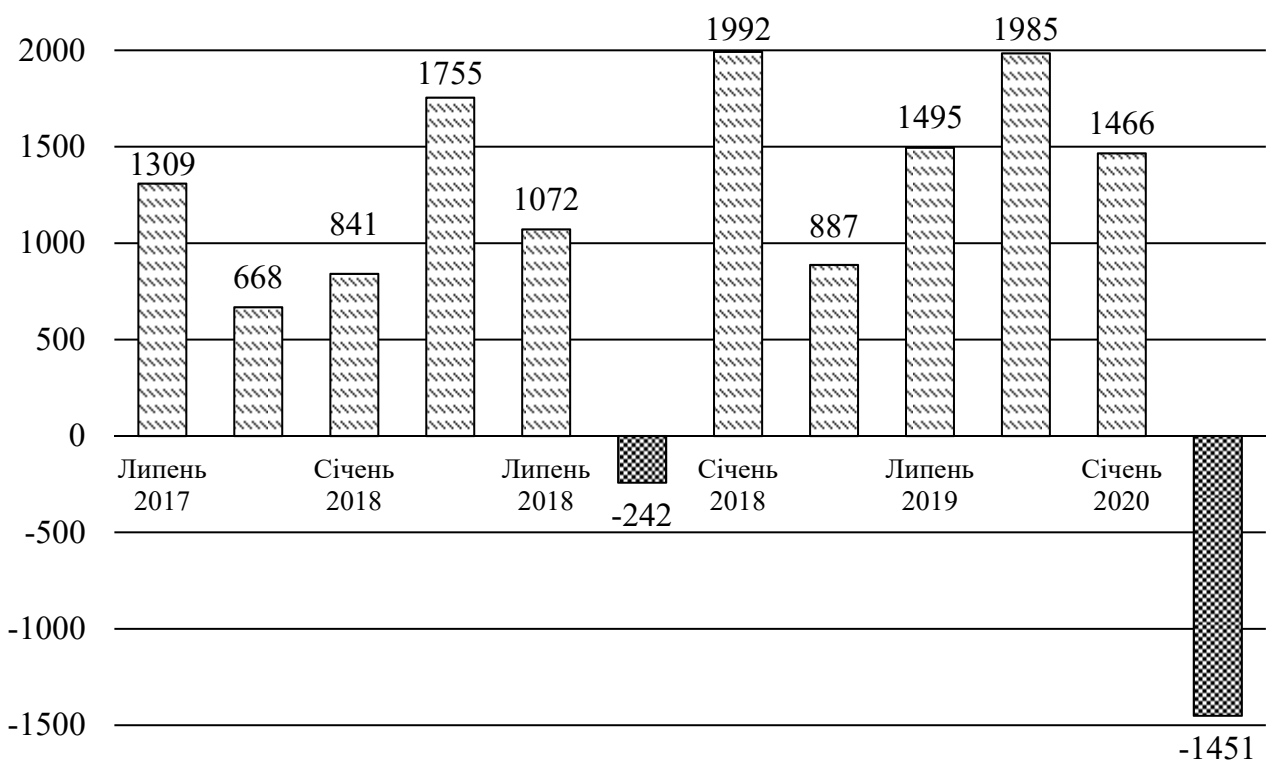

$-2000$

Рис. 2. Чистий притік ПІІ в Украӥну, 2017-2020 рр. (зміна запасу ПІІ), млн дол. США

Економіки (топ-20), які мають найвищий бал за зручність ведення бізнесу, мають кілька спільних рис: процеси реєстрації бізнесу в Інтернеті, електронні платформи подання податків та онлайн-процедури, пов'язані з передачею майна. Більше того, 11 економік мають електронні процедури отримання дозволів на будівництво. Загалом 20 найкращих виконавців мають належне регулювання бізнесу з високим ступенем прозорості. Середні показники цих економік становлять 12,2 (із 15) щодо індексу контролю якості будівлі, 7,2 (із 8) - щодо надійності постачання та індексу прозорості тарифів, 24,8 (із 30) - щодо якості індексу адміністрації земель та 13,2 (із 18) - щодо показника якості судових процесів. Чотирнадцять із 20 найкращих виконавців мають єдиний реєстр застави, а 14 дають змогу життєздатному бізнесу продовжувати працювати як діюча компанія під час провадження у справі про неплатоспроможність. Різниця в досвіді підприємця в економіках із найвищою та нижчою ефективністю виразна майже в усіх сферах ведення бізнесу. Наприклад, для того щоб розпочати бізнес в економіці, що входить до нижчої 50-ки, у середньому потрібно майже у шість разів довше, ніж у топ-20. Передача власності в 20-ти кращих економіках вимагає менше двох тижнів порівняно з приблизно трьома місяцями у нижній 50-ці. Отримання підключення до електроенергії в середній економіці нижньої 50-ки займає вдвічі більше часу, ніж у середній економіці топ-20; вартість такого зв'язку в 44 рази вища, якщо виражати його як частку доходу на душу населення. Окрім того, вирішення комерційних суперечок триває близько 2,1 року в економіках, що посідають 50-е місце порівнянні з 1,1 року у 20 країнах. Помітні відмінності між сильнішими та слабшими економіками також виявляються в якості регулювання та інформації. У топ-20 83\% дорослого населення в середньому охоплено або кредитним бюро, або реєстром, тоді як у нижчих 50 середнє охоплення становить лише $10 \%$.

Сінгапур є країною зі сприятливим інвестиційним кліматом не лише завдяки низьким податкам, яких усього п'ять. До мінімуму зведено бюрократичні процедури для 
бізнесу, вся звітність - через Інтернет (при цьому ії дуже мало). У країні повністю скасували «дозвільну» практику і «ліцензування». У Сінгапурі відсутні податки на дивіденди, капіталізований капітал, банківські відсотки та інвестиційний дохід [5].

У Гонконзі процес бізнес-функціонування максимально зручний. Підприємці незалежно від національної приналежності мають доступ до розвиненої фінансової та юридичної галузі, надійним і недорогим комунальним послугам, передовим комунікаціям та інформаційної інфраструктури. Більше того, владою Гонконгу передбачено цілу низку грантів та спонсорських програм, мета яких - фінансова й освітня допомога колективам, які працюють в інтелектуальній сфері [6].

У 2020 р. Україна піднялася на сім позицій і посіла 64-е місце порівняно 3 71-м місцем зі 190 у 2019 р. (участь у рейтингу бере з 2006 р. і лише у 2015 р. потрапила до першої сотні). Найгіршу позицію Україна мала у 2012 р. - 152-е місце зі 183. Позитивні зміни стосуються спрощення процедур та здешевлення отримання дозволів на будівництво, підключення до електромереж, реєстрації власності, реєстрації бізнесу, посилення захисту прав міноритарних інвесторів, поліпшення умов міжнародної торгівлі, доступу до кредитної інформації, виконання контрактів.

3. Територія як місце для інновацій (напрям сприяє задоволенню потреби молодих бізнесменів у креативному підході до підприємництва). Регіон може бути не лише об’єктом для прямих або непрямих інвестицій, а й місцем для реалізації найсміливіших інновацій. Яскравим прикладом слугує знаменита Силіконова долина. Реалізується концепція також в інших регіонах. Наприклад, прийшовши в 2007 р. до влади, Н. Саркозі став активно втілювати в життя політику, націлену на розвиток інновацій, що знайшло вираження у підтримці високотехнологічних виробництв, створенні науково-виробничих кластерів, розвитку регіональних інноваційних мереж, модернізації системи вищої освіти і наукових досліджень. Найбільш помітними перетвореннями у сфері інноваційної політики стали полюса конкурентоспроможності (ПК, 2004 р.) та полюса наукових досліджень і вищої освіти (ПНІВ, 2006 р.), а також заходи, спрямовані на розвиток університетської автономії (2007р.) [7]. Полюси конкурентоспроможності - це об'єднання підприємств, дослідницьких організацій та освітніх центрів, які розташовані на одній території, включені в спільну діяльність і призначені для генерації синергії в інноваційних проєктах молодих підприємців [8]. Основою діяльності ПК ставали науково-технічні та інноваційні проєкти, спрямовані на розвиток національної і регіональної економіки.

Загальновизнано, що інноваційно-освітні кластери є ефективним механізмом розвитку регіональної інноваційної підприємницької системи [9].

У Гонконзі особлива увага приділяється культивації навичок щодо трансмісії досягнень інноваційного процесу на ринки ресурсів та готової продукції [6]. До послуг компаній, що займаються науковими розробками, створено численні і доступні високотехнологічні спеціалізовані центри, метою функціонування яких $\epsilon$ допомога у розвитку/комерціалізації перспективних ідей.

Співпраця між університетами, державними структурами, громадськими організаціями та бізнесом дає змогу налагоджувати та реалізовувати ефективні механізми підтримки молодіжного інноваційного підприємництва за рахунок синергетичних ефектів, що досягаються в ході такої взаємодії. Окрім того, лише на базі такого співробітництва можна створити умови для сталого розвитку міжуніверситетських стартап-центрів та популяризації молодіжного підприємництва.

Одним із головних індикаторів, узагальнюючим показником для вимірювання рівня та результатів реалізації інноваційного потенціалу країни є Глобальний інноваційний індекс, у якому знаходять своє відображення основні складники інноваційного потенціалу країн [5]. Результати дослідження позиції України за складниками Глобального інноваційного індексу наведено в табл. 2. 
Таблиця 2

Оцінка позиції України за складниками Глобального інноваційного індексу [11]

\begin{tabular}{|c|c|c|c|c|c|c|c|c|c|c|c|c|}
\hline \multirow{2}{*}{$\begin{array}{c}\text { Складники } \\
\text { Глобального } \\
\text { інноваційного } \\
\text { індексу }\end{array}$} & \multicolumn{2}{|c|}{2014} & \multicolumn{2}{|c|}{2015} & \multicolumn{2}{|c|}{217} & \multicolumn{2}{|c|}{2018} & \multicolumn{2}{|c|}{2018} & \multicolumn{2}{|c|}{2019} \\
\hline & ฮี & $\stackrel{\mathscr{\vartheta}}{\frac{\vartheta}{3}}$ & ธี & 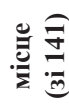 & ธี & 氖 & ฮี & 氖 & ธี & 总 & ฮี & : \\
\hline $\begin{array}{l}\text { Глобальний } \\
\text { інноваційний } \\
\text { індекс }\end{array}$ & 36,3 & 63 & 36,5 & 64 & 35,7 & 56 & 37,6 & 50 & 38,5 & 43 & 37,4 & 47 \\
\hline Інституції & 52,9 & 103 & 52,8 & 98 & 48,7 & 101 & 47,9 & 101 & 49,1 & 107 & 53,9 & 96 \\
\hline $\begin{array}{l}\text { Людський капітал } \\
\text { і дослідження }\end{array}$ & 36,6 & 45 & 40,4 & 36 & 40,8 & 40 & 39,6 & 41 & 37,9 & 43 & 35,6 & 51 \\
\hline Інфраструктура & 27,1 & 107 & 26,3 & 112 & 32,3 & 99 & 39,3 & 90 & 38,1 & 89 & 36 & 97 \\
\hline $\begin{array}{l}\text { Рівень розвитку } \\
\text { ринку }\end{array}$ & 45,1 & 90 & 43,9 & 89 & 42,1 & 75 & 43,2 & 81 & 42,7 & 89 & 43,3 & 90 \\
\hline $\begin{array}{l}\text { Рівень розвитку } \\
\text { бізнесу }\end{array}$ & 29,1 & 87 & 32,4 & 78 & 30,6 & 73 & 35,3 & 51 & 34,5 & 46 & 34,8 & 47 \\
\hline $\begin{array}{l}\text { Результати } \\
\text { застосування } \\
\text { знань та } \\
\text { технологій }\end{array}$ & 38,2 & 32 & 36,4 & 34 & 34,1 & 33 & 32,8 & 32 & 36,7 & 27 & 34,6 & 28 \\
\hline $\begin{array}{l}\text { Результати } \\
\text { творчої діяльності }\end{array}$ & 30,6 & 77 & 31,3 & 75 & 31 & 58 & 35,6 & 49 & 36,5 & 45 & 33,3 & 42 \\
\hline
\end{tabular}

Проаналізувавши стан розвитку інноваційної діяльності в Україні за допомогою Глобального інноваційного індексу, можна зазначити, що у період 2016-2018 pp. спостерігається підвищення значення індексу, що свідчить про поступове поліпшення ситуації у сфері інновацій в Україні. Також варто зазначити, що в 2018 р. порівняно 3 2017 р. відбулося підвищення ефективності інновацій, що дало змогу Україні посісти 43-є місце серед 126 країн за показником індексу ефективності інновацій. Проте в 2019 р. відбулося зниження позицій, і Україна втратила чотири позиції та перейшла на 47-е місце серед 129 країн. У розрізі показників України має таку ситуацію: політична і операційна стабільність - 125-е місце зі 129-ти, ефективність уряду - 95-е, верховенство права - 107-е, легкість початку бізнесу - 48-е, легкість вирішення проблеми неплатоспроможності - 115-е, освіта - 43-є, вища освіта - 37-е, інформаційні та комунікаційні технології - 81-е, урядові онлайн-послуги - 92-е, загальна інфраструктура - 95-е, екологічна стійкість - 120-е, кредитування - 91-е, легкість отримання кредитів - 29-е, кредитування приватного сектору - 86-е, інвестиції - 115-е, кваліфіковані працівники - 45-е, створення знань (патенти, винаходи) - 17-е (у цьому розділі за показником корисні моделі за походженням - 1-е місце), вплив на знання - 47-е, поширення знань - 47-е, нематеріальні активи - 17-е, креативні товари і послуги - 91-е, креативність в онлайн - 43-є [11].

Зважаючи на такі тенденції, доцільно звернути увагу на забезпечення брендингу територій та стимулювання молодих людей розвивати бізнес. При цьому до брендування території як зручного місця для проживання переважно вдаються ті регіони, які відчувають проблеми з відтоком населення. Однак і регіонам, які такої проблеми не відчувають, не слід забувати про даний вид брендингу, оскільки важливі не просто жителі, а реальний бізнес як платник податків, які поповнюють місцеві бюджети. 
Одним із напрямів розвитку брендингу території є iї використання для проведення різного роду ділових заходів (виставок, конгресів, тренінгів). В останні роки все більше компаній намагаються організовувати ділові зустрічі, конференції, проводити семінари за кордоном. Більшою мірою це, звичайно, стосується компаній міжнародних, адже учасники заходу їдуть з усіх кінців світу і логічніше його проводити в зручному та доступному для всіх місці. Тому створення іміджу території, привабливого для бізнес-мандрівників, $є$ дуже перспективним напрямом брендингу території. Окрім організації гостинного місця для ділових зустрічей, до такого роду заходів можна віднести проведення різного роду міжнародних виставок і ярмарків.

Традиційними лідерами в даній сфері виступають Австрія, Німеччина, Великобританія, Франція і Швейцарія.

4. Туризм розглядається як найперспективніший елемент формування брендингу країни [14]. Завдання брендингу: регіон - приваблива територія для бізнес-подій (сприяє нетворкингу молодих підприємців, обміну досвідом, формуванню мотивації). Відносно недавно з'явився і став активно розвиватися такий напрям ділового туризму, як інсентив-туризм. Під ним розуміють подорожі, якими компанії нагороджують своїх співробітників і партнерів за високі результати роботи. До основних видів такого туризму відносять заохочувальні поїздки, поїздки, суміщені з діловими заходами, виїзди, що мають на меті тимбілдинг.

Лідерами у цьому напрямі є європейські країни та США. Однак з’являються і такі нові гравці, як країни Південно-Східної Азії. Особливий інтерес становить досвід Італії, яка прагне використовувати як традиційні, так і нестандартні підходи в залученні ділових мандрівників. Як приклад можна привести інсентівтури за кермом Ferrari. Організатори таких турів стверджують, що «подорожі за кермом Ferrari - це унікальні у своєму роді подорожі, оскільки вони дарують емоції, які можна отримати виключно в Італії і тільки за кермом Ferrari, що несуть неповторну чарівність італійського стилю життя» [10].

Україна займала активну позицію у проведенні подібного роду заходів, особливо що стосується фестивалів, тренингів тощо. За останній рік відбулося падіння їх кількості та переведення, якщо це можливо, у дистанційний режим у зв'язку з пандемією COVID-19.

У 2018 р. громадська організація Центр розвитку «Демократія через культуру» провела дослідження ролі мистецьких фестивалів у саморозвитку громад. У рамках дослідження було ініційовано опитування представників громад, організаторів фестивалів та туристичних організацій із метою з'ясування їхньої готовності до співпраці. Зі 183 місцевих громад, що взяли участь в опитуванні, 173 погодилися з твердженням, що саме культурно-мистецькі фестивалі можуть привернути до них увагу туристів. Натомість лише 2 з 65 опитаних фестивалів і 1356 туристичних організацій, що брали участь у дослідженні, не ставлять перед собою такого завдання.

Отже, на рівні громад є бачення фестивалів як туристичного ресурсу. Проте, окрім розуміння і бажання громад проводити фестивалі, потрібно вимірювати вплив фестивалів на розвиток туризму в регіонах, демонструвати конкретні показники задля формування стратегії розвитку туризму в регіоні, зокрема йдеться і про івент-стратегію.

За останні два роки Україна піднялася на 10 позицій в Індексі конкурентоспроможності у сфері подорожей і туризму та зайняла там 78-е місце за рахунок найшвидшого темпу зростання в субрегіоні. Зокрема, у міру стабілізації та відновлення країни Україна різко поліпшила ділове середовище (зі 124-го на 103-є місце), безпеку (зі 127-го на 107-е місце), міжнародну відкритість (із 78-го на 55-е місце) і загальну інфраструктуру (із 79-го на 73-є місце ).

5. Завдання брендингу: підвищення привабливості території та розвиток територіального бренду як місця для отримання освіти (сприяє підвищенню якості бізнес- 
освіти та формує засади співпраці). Саме освітнє середовище $є$ однією 3 ключових груп стейхолдерів, які сприяють розвитку молодіжного підприємництва, про що свідчить світовий досвід.

У Франції з метою реформування науково-дослідних і навчальних закладів проводилася політика розвитку кооперації між вищими навчальними закладами - університетами і дослідницькими структурами (Полюса наукових досліджень і вищої освіти - ПНІВ), розташованими в одній географічній зоні, з метою об'єднання зусиль на певних наукових напрямах і ефективного використання наявних в їх розпорядженні ресурсів. Так з'явилися ПНІВ «Сорбонна - Університети», «Париж - наука і література. Латинський квартал». Велика увага приділялася інтеграції університетів у життя території, де вони розташовані. Представники територіальних органів влади беруть участь в адміністративних радах університетів, впливають на вироблення університетської політики, займаються реконструкцією університетських будівель і гуртожитків, виділяють стипендії, фінансують наукові дослідження. Своєю чергою, університет прагне адаптувати надану освіту до потреб локального ринку праці [10].

Вища освіта в Україні - вибір не лише перспективної української молоді, а й безлічі студентів ближнього зарубіжжя й азіатських країн. Найбільше молоді приїжджає вступати до українських вишів із Туркменістану, Азербайджану, Індії, Нігерії, КНР, Іраку та Росії. А найбільш затребуваними напрямами підготовки в Україні для іноземців є медицина, економіка, право, інженерія та авіація.

Розвиток кожного з описаних напрямів дасть змогу створити та популяризувати територіальний брендинг, допомогти молоді розвивати місто, де мешкає, залучити інвестиції. Територіальний брендинг - це шлях до розвитку молоді, що пишається рідним містом та може реалізувати себе й упровадити свої інноваційні ідеї не виїжджаючи за кордон.

Висновки. У статті проаналізовано феномен територіального брендингу в контексті розвитку привабливості регіону та стимулювання молоді до ведення бізнесу й популяризації території. У ході дослідження було встановлено, що реалізація концепції брендингу спрямована на вирішення таких завдань:

- формування детермінантів підвищення рівня самоототожнення/самоідентифікації молоді з територією проживання та, як наслідок, конструювання стійкої позитивної регіональної ідентичності й мотивації до реалізації підприємницької активності;

- орієнтування жителів на рішення місцевих проблем і активізація їхньої участі у суспільно-політичному житті громади;

- залучення в регіон нових інвесторів;

- популяризація продукції, виробленої на території суб'єкта, на локальному, регіональному, національному, світовому рівнях;

- збільшення туристичного потоку;

- привернення уваги влади та наднаціональних структур до можливостей і загроз регіону з погляду стратегічного партнерства у програмних і проєктних пропозиціях;

- підвищення привабливості регіону для потенційних мігрантів, передусім для висококваліфікованих фахівців працездатного віку і молоді.

Важливість територіального брендингу для молодих підприємців важко переоцінити, тому що навіть за максимально сприятливої економічної кон'юнктури і наявності високо кваліфікованих управлінських кадрів молодь як суб'єкт бізнесу вразливіша за інші вікові групи через низку причин. Реалізація ж перерахованих вище завдань матиме результатом: розвиток ефективної інформаційної інфраструктури; забезпечення конкурентного ринкового середовища та посилення конкурентоспроможності молодих підприємців на міжрегіональному і міжнародному рівнях; підвищення рівня технічного й інноваційно-технологічного забезпечення підприємств; створення привабливих умов для інвестування та активізації діяльності кредитних установ, 
у цілому - поліпшення доступу до фінансових ресурсів; створення умов для реструктуризації економічно слабких суб'єктів господарювання; удосконалення організаційної структури, форм та змісту маркетингування на рівні регіону та фірм; розроблення і реалізацію в регіоні соціальних програм щодо поліпшення якості життя.

\section{Список використаних джерел:}

1. Шарков Ф.И. Брендинг и культура организации. Москва, 2003. С. 95.

2. Рожков И.Я. Реклама: планка для «профи». Москва, 1999. С. 97.

3. Терминологический словарь маркетинга. URL: http://www.marketing/spb.ru/read/doc/ (дата звернення: 10.10.2020).

4. Добробабенко Н.C. Mission \& vision: ценности марки и основа корпоративной стратегии. Реклама. Advertising. 2000. № 1. С. 14.

5. Doing Business 2020. URL: https://openknowledge.worldbank.org/bitstream/handle/10986/ 32436/9781464814402.pdf (дата звернення: 10.10.2020).

6. Center on Global Brand Leadership. URL: http://www.globalbrands.org (дата звернення: 10.10.2020).

7. Король А.Н. Брендинг как синтетическая маркетинговая коммуникация фирмы. Практический маркетинг. 2005. № 12. С. 11.

8. Архангельская К.В. Бренд как объект исследования. Известия Уральского государственного университета. 2006. № 47. С. 52-58.

9. Міжнародна консалтингова агенція Brandflight. URL: http://www.brandflight.com/ru/ branding/ (дата звернення: 10.10.2020).

10. Шульгіна Л.М., Лео М.В. Брендинг: теорія та практика (на прикладі об'єктів комерційної нерухомості) : монографія. Київ : Астон, 2011. 272 с.

11. The Global Innovation Index 2019. URL: https://www.wipo.int/edocs/pubdocs/en/wipo_pub_ gii_2019.pdf (дата звернення: 10.10.2020).

12. Кирилов Ю.С., Крикунова В.М., Жосан Г.В. Корпоративна соціальна відповідальність у системі підприємницької діяльності: трансформація підходів і напрямів оцінювання. Економічні інноваціï. 2019. Т. 21. Вип. 1 (70). С. 52-63. URL: https://www.google.com/url?sa=t\&rct=j\&q=\& esrc $=$ s\&source $=$ web \& $\mathrm{cd}=1 \& \mathrm{ved}=2 \mathrm{ahUKEwiY4f-imI7kAhUhmYsKHblHD2IQFjAAegQIARAC \& u}$ $\mathrm{rl}=\mathrm{http} \% 3 \mathrm{~A} \% 2 \mathrm{~F} \% 2 \mathrm{Fwww}$.ei-journal.com\%2Findex.php $\% 2 \mathrm{Fjournal} \% 2 \mathrm{Farticle} \% 2 \mathrm{Fdownload} \% 2 \mathrm{~F} 57$ 7\%2F232\&usg=AOvVaw1-m8M2DTul3HZGQY9axPVT (дата звернення: 10.10.2020).

13. Жосан Г.В. Особливості взаємодії груп стейкхолдерів молодіжного підприємництва. Вчені записки ТНУ. Серія «Економіка і управління». 2020. Т. 31 (70). № 3. С. 150-155. URL:

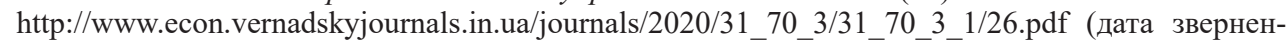
ня: 10.10 .2020$)$.

14. Кирилов Ю.С. Бренд країни в глобалізованому світі. Херсон : Грінь Д.С., 2013. 156 с.

\section{References:}

1. Sharkov F.Y. (2003) Brending i kul'tura organizatsii [Organizational branding and culture]. Moscow. (in Russian)

2. Rozhkov Y.Ya. (1999) Reklama: planka dlya «profy» [Advertising: the bar for the "pros"]. Moscow. (in Russian)

3. Terminologicheskiy slovar' marketinga. Available at: http://www.marketing/spb.ru/read/doc/ (accessed 10 October 2020).

4. Dobrobabenko N.S. (2000) Mission \& vision: tsennosti marki i osnova korporativnoy strategii [Mission \& vision: brand values and corporate strategy]. Reklama. Advertising, no. 1, pp. 14.

5. Doing Business 2020 (2020). Available at: https://openknowledge.worldbank.org/bitstream/ handle/10986/32436/9781464814402.pdf (accessed 10 October 2020).

6. Center on Global Brand Leadership. Available at: http://www.globalbrands.org (accessed 10 October 2020).

7. Korol A.N. (2005) Brending kak sinteticheskaya marketingovaya kommunikatsiya firmy [Branding as a synthetic marketing communication of a company]. Prakticheskiy marketing, no. 12, pp. 11.

8. Arkhangel'skaya K.V. (2006) Brend kak ob'ekt issledovaniya [Brand as an object of research]. Y Izvestiya Ural'skogo gosudarstvennogo universiteta, no. 47, pp. 52-58. 
9. Mizhnarodna konsaltyngova agenciya «Brandflight». [International Consulting Agency «Brandflight»]. Available at: http://www.brandflight.com/ru/branding/ (accessed 10 October 2020).

10. Shul 'gina L.M., Leo M.V. (2011) Brendynh: teoriia ta praktyka (na prykladi obiektiv komertsiinoi nerukhomosti) [Branding: theory and practice (on the example of commercial real estate)]. Kyiv: Aston. (in Ukrainian)

11. The Global Innovation Index 2019. Available at: https://www.wipo.int/edocs/pubdocs/en/ wipo_pub_gii_2019.pdf (accessed 10 October 2020).

12. Kyrylov Yu.Ye., Krykunova V.M., Zhosan H.V. (2019) Korporatyvna sotsialna vidpovidalnist u systemi pidpryiemnytskoi diialnosti: transformatsiia pidkhodiv i napriamiv otsiniuvannia [Corporate social responsibility in the system of entrepreneurial activity: transformation of approaches and directions of evaluation]. Ekonomichni innovaciyi, vol. 21, no. 1 (70), pp. 52-63. Available at: https://www.google.com/url? sa=t\&rct=j\&q=\&esrc=s\&source=web\&cd=1\&ved=2ahUKEwiY4fimI 7kAhUhmYsKHblHD2IQFjA AegQIARAC\&url=http\%3 A \%2F\%2Fwww.ei-journal.com $\% 2$ Findex.php $\% 2$ Fjournal $\% 2$ Farticle $\% 2$ Fdownload $\% 2$ F $577 \% 2 \mathrm{~F} 232 \&$ usg $=\mathrm{AOv}$ Vaw1-m8M2DTul3HZGQY9axPVT (accessed 10 October 2020).

13. Zhosan G.V. (2020) Osoblyvosti vzaiemodii hrup steikkholderiv molodizhnoho pidpryiemnytstva [Features of interaction of groups of stakeholders of youth entrepreneurship]. Vcheni zapysky TNU. Seriia «Ekonomika i upravlinnia», vol. 31 (70), no. 3, pp. 150-155. Available at: http://www.econ.vernadskyjournals.in.ua/journals/2020/31_70_3/31_70_3_1/26.pdf (accessed 10 October 2020).

14. Kyrylov Yu.Ie. (2013) Brend krainy v hlobalizovanomu sviti [The country's brand in a globalized world]. Kherson: Hrin D.S. (in Ukrainian) 